\title{
TAXING UNSETTLED. INCOME: THE "CLAIM OF RIGHT" TEST
}

For administrative convenience, the Federal Government bases computation of taxable income on a rigorous annual accounting of its taxpayers' financial status. ${ }^{1}$ But while strict annual accounting does simplify the Government's task of collection, it can also cause severe hardship to the taxpayer whose business transactions do not conform to arbitrary tax periods. ${ }^{2}$ Especially is this true where the taxpayer is in receipt of income ${ }^{3}$ which, though presently in his hands, may have to be returned to a subsequent rightful owner in a later taxable year."

In such situations the taxpayer would like either to avoid taxation by not reporting the income immediately, or, having paid the tax, to be certain of an equalizing refund. Both courses are precluded by the basic principle of annual accounting that each tax year is a separate entity. ${ }^{5}$ Under this prin-

1. Section 41 of the Internal Revenue Code provides that "net income shall be computed upon the basis of the taxpayer's annual acounting period ... in ascordance with the method of accounting regularly employed in keeping the bools of stch taxpayer. . ." See U. S. Treas. Reg. 111, $\$ 29.41-1$ to $29.41-4$ inclusive (1943). The accounting period may be either a calendar or a fiscal year; a fiscal year is defined as "an accounting period of twelve months ending on the last day of any month other than December." Irr. Rer. CODE, $\$ 48(b)$.

The Supreme Court has stated the principles underlying annual accounting as follows: "The Sixteenth Amendment was adopted to enable the government to raise revenue by taxation. It is the essence of any system of taxation that it should produce revenue ascertainable, and payable to the government, at regular intervals. Only by such a system is it practicable to produce a regular flow of income and apply methods of accounting, assessment, and collection capable of practical operation. ... While, conceivably, a different systein might be devised by which the tax could be assessed, wholly or in part, on the basis of the finally ascertained results of particular transactions, Congress is not required by the amendment to adopt such a system in preference to the more familiar method, even if it were practicable" Burnet v. Sanford \& Brooks Co, 282 U.S. 359, 365 (1931).

While net income must be computed with respect to a fixed twelve month periof, the time of reporting items of income and talking deductions will depend upon whether the taxpayer is using the "cash basis" or "accrual basis" of accounting. See note 6 isfro.

2. Illustrations are collected in Hendersors, Irrroduction to Incoss TAxatro:r $\S 49$ (1943).

3. The term "income," as well as more generic terms such as "monies," "funds" and "receipts" will be used to refer to items which are includcd in "gross income" as defined by both Section 22(a) of the Internal Revenue Code (quoted in note 15 isfra) and the courts (see note 38 sirfra).

4. Either calendar or fiscal. See note 1 suspra.

5. 'Each year's return, so far as practicable, both as to gross income and dedustions therefrom, should be complete in itself. . . . The expenses, liabilities, or defieit of one year cannot be used to reduce the income of a subsequent year." U. S. Treas. Reg. $111, \S 29.43-2$ (1943). For a discussion of the rule and cases applying it, see 2 MiEsTs:s, LAW OF FEDERAL InCOASE TAXATION $\$ 12.06$ (1942) (Supp. 194S) (hereinafter referred to as MERTENS). There are exceptions, however. See note 49 infro. 
ciple, items of gross income are properly taxable in the tax year in which they are accrued or received, depending upon the taxpayer's accounting method. ${ }^{6}$ Deductions from income may not be taken until liability for restitution becomes fixed or until return is actually made. ${ }^{7}$ And even then, a deduction cannot be related back to an earlier year as the basis for recovering the original tax payments. ${ }^{8}$

It is this independent treatment in two separate tax years of one transaction intimately related to both time periods which creates the potential for hardship to the taxpayer, since a deduction in the year of restitution may only slightly mitigate his earlier tax expense. Restitution may take place either in a year of lower tax rates or in a year when the taxpayer's decreased income places him in a lower tax bracket, so that even a full deduction would not compensate for the original tax. ${ }^{9}$ And where a taxpayer's net income is

6. INI. Rev. CODE §42(a); U. S. Treas. Reg. 111, §29.42-1 (1943). Roughly stated, under the cash method, which is employed by most individuals, income is accounted for in the year received, and deductions are taken only in the year cash payments are made. Under the accrual method, on the other hand, income is to be accounted for in the year in which the right to receive it becomes fixed, even though it is not actually received; deductions are to be taken in the year in which the items deducted are incurred, whether actually paid or not. INT. REv. CoDE $\$ \$ 42(a), 43 ;$ U. S. Treas. Reg. $111, \S 29.42-1$. See 2 Mertens, $\$ \S 12,13$. The distinction is clearly drawn in Spring City Co. v. Commissioner, 292 U.S. 182, 184-5 (1934).

Apparently, once items of unsettled income are received, the accrual basis taxpaycr may no longer delay taxation merely because his right to the receipts is still contingent. See note 20 infra.

7. Depending upon whether the taxpayer is on the accrual or cash basis. Sco note 6 supra. Cases applying the rule are manifold. E.g., Security Flour Mills Co. v. Commissioner, 321 U.S. 281 (1944) ; Brown v. Helvering, 291 U.S. 193 (1934); Lucas v. American Code Co., 280 U.S. 445 (1930).

The term "return" and others which indicate repayment will be used to mean both (1) actual payments by cash basis taxpayers, and (2) the final determination of an accrual basis taxpayer's liability.

8. "The deductions and credits... shall be taken for the taxable year in which 'paid or accrued' or 'paid or incurred' ... unless in order to clearly reflect the income the deductions or credits should be taken as of a different period." INT. REv. CODE $\$ 43$. See U.S. Treas. Reg. 111, \$29.43-1 (1943). See Burnet v. Sanford \& Brooks Co., 282 U.S. 359, 365 (1931). The "unless" clause, added in 1924, could be interpreted as a counter rule to the rigors of annual accounting. See Helvering v. Cannon Valley Milling Co., 129 F.2d 642, 646 (8th Cir. 1942) ("We think the guide for construction of this 'unless' clause is that it comprehends those exceptional situations where it is necessary to transfer a deduction item in order to avoid such a distortion of income as would produce an injustice."). But the Supreme Court has so narrowly construed the clause that little elasticity remains. Security Flour Mills Co. v. Commissioner, 321 U.S. 281 (1944).

9. Restitution may, of course, take place in a year of higher tax rates or larger gross income, permitting a deduction which would more than offset the original tax. See note 47 infra. But most types of unsettled income are unusual receipts which substantially increase total income of the year in which received. See, for example, the cases mentioned in notes $24-7$ infra. 
negligible, the right to deduct repayment as a loss is even colder comfort. ${ }^{10}$

Despite this potential for hardship, the Government considers that annual accounting of unsettled receipts is dictated by practical considerations. Immediate taxation is desirable since intervening insolvency might deprive the Government of taxes on the income. ${ }^{11}$ Further, the sovereign wishes to avoid the administratively difficult problems of defining income which is "certain" and of examining previous tax years to determine an equalizing refund. ${ }^{12}$

The Treasury's understandable refusal to relax the rigors of annual accounting has forced the taxpayer to seek relief in the courts. ${ }^{13}$ But his efforts either to take an immediate deduction for anticipated future losses or to relate present losses back to the year of receipt have been unsuccessful. ${ }^{14}$ Failing to breach the walls of annual accounting, the taxpayer has tried to flank them by persuading the courts that items which would otherwise be taxable as "gross income" are rendered non-taxable either by their doubtful permanence or by their subsequent restitution. ${ }^{15}$ The verbal

10. Moreover, in some instances items which constitute taxable income when received may not be allowable deductions when restored. An OPA violator, for example, prior to the enforcement of his obligation to return overcharges, must count them as taxable income. See United States v. Currier Lumber Co., 70 F. Supp. 219, 221 (D.C.Mlass. 1947). Yet Government recovery of the overcharges does not give rise to a deductible loss. Garibaldi \& Cuneo, 9 T.C. 446 (1947); Scioto Provisions Company, 9 T.C. 439 (1947). The administrative rulings which precipitated the litigation are I.T. 3627, 1943-1 Cun. BuLl. 111; I.T. 3630, 1943-1 Cux. BurI 113; I.T. 3799, 1946-1 Cons. BuLr. 56.

11. See Disney, J., dissenting in Alamitos Land Co., 40 B.T.A. 353, 364 (1939), rev'd, 112 F.2d 648 (9th Cir. 1940). Commentators concur. See, e.g., 2 Cconnnisto3s, CyCLOPEDIC TAX SERVICE $\$ 211.04$ (1945) : "To hold otherwise would result in permittins the tax liability to be projected indefinitely into the future, thereby causing the Government to assume the hazards of business with no share in its management."

12. See, e.g., National City Bank of New York v. Helvering, 98 F.2d 93, 96 (2d Cir. 1938) ("Possession is in general prima facie evidence of ownership. . . [C] [llection of the revenues cannot be delayed, nor should the Treasury be compelled to decide when a possessor's claims are without legal warrant.").

13. If the taxpayer wishes to challenge the Commissioner's ruling, he can either (a) refuse to pay the tax and appeal to the Tax Court, or (b) pay the tax and sue for a refund in the federal courts, including the Court of Claims. See B. N. A., Pescricar Aspects of Federal Taxation Pt. 24, 25 (1946); Practice and Procedune Berone tHe TAX Court of the UnIted States.

14. The first of these attacks upon annual accounting has been repelled by the general proposition that a taxpayer, whatever his accounting method, may not deduct a contingent liability. E.g., Dixie Pine Products Co. v. Commissioner, 320 U.S. 516 (1944) ; Brown r. Helvering, 291 U.S. 193 (1934). The second has been blocked by restatements of the annual accounting principle that one year has absolutely nothing to do with the next. See Burnet v. Sanford \& Brooks Co., 282 U.S. 359, 365 (1931). A more detailed account may be found in 2 MIERTENS $\$ \$ 12.61,12.66,12.67$.

15. Section 22(a) of the Internal Revenue Code defines "gross income" in part as "gains, profits and income ... derived from any source whatever." Judicial definition has been similarly broad. See, e.g., Eisner v. Mracomber, 252 U.S. 189, 207 (1920) ("the 
judicial response has usually been that income, however unsettled or transient, is properly taxable in the year the taxpayer received it under a "claim of right."

\section{The "Claim of Right" Doctrine}

When courts speak of income held under a "claim of right," they generally mean that the taxpayer has received and treated the monies as his own. ${ }^{16}$ Some doubt is cast, however, as to whether this personal claim, usually determined by the taxpayer's outward treatment of the funds, is the sole or proper test specified by the doctrine. This doubt arises from the ambiguous phraseology of the Supreme Court in North American Oil Consolidated $v$. Burnet, ${ }^{17}$ the case in which the doctrine originated seventeen years ago. ${ }^{18}$ There the company, upon the entry of a lower court decree in $1917^{\circ}$, had received earnings from the operation of oil lands. ${ }^{19}$ Although the

gain derived from capital, from labor, or from both combined ..."). Accrual basis taxpayers sought to establish that unconditional right to income, irrespective of its receipt, was the foundation of the right to accrue. Cash basis taxpayers maintained that unsettled sums were in the nature of loans until the right to retention became certain. See, e.g., Jacobs v. Hoey, 136 F.2d 954, 956 (2d Cir. 1943).

16. See, e.g., Moore v. Thomas, 131 F.2d 611, 613 (5th Cir. 19.12): "Of first importance to the determination of whether the moneys in question are taxable as income to the taxpayer in the year in which they were received is a determination, not only of the circumstances under which the taxpayer took the moneys and how it used them, but as to the intention and understanding under which they were paid to and received by it. The decisions make it clear that moneys received by the taxpayer are treated as his earnings and are taxed to him as income in that year when the taxpayer by his conduct has affirmed that they are, because under the taxing system adopted, it is the reasonable and practical thing to accept his view." And see cases cited in notes 24-7 infra. But this "reasonableness" does not appear to run both ways: the taxpayer cannot avoid a tax by calculated efforts not to treat income as his own. See p. 964 infra.

The commentators too have interpreted "claim of right" as a touchstone of personal attitudes. 2 CoORdinators, op. cit. supra note $11, \S 203.12(2) ; 2$ Mertens $\$ 12.103$; 1 Montgonery, Federal Tax Handbook 11 (1940).

17. 286 U.S. 417 (1932).

18. The phrase "claim of right" had been mentioned casually one year earlier in a dictum in Board v. Commissioner, 51 F.2d 73, 75 (6th Cir. 1931). Prior to the doctrine's establishment in the North American case, courts had generally laid down the blanket rule that monies which met the substantive test of "gross income" were taxable in the year in which they were received by the taxpayer. E.g., Burnet v. Sanford \& Brooks Co., 282 U.S. 359 (1931); Lucas v. American Code Co., 280 U.S. 445 (1930); Highland Milk Condensing Co. v. Phillips, 34 F.2d 777 (3d Cir. 1929). But some courts, most notably the Board of Tax Appeals, favored tax refunds upon restitution, apparently on the theory that the monies were not "gross income" in the first place. V. T. Lilly, 14 B.T.A. 703 (1928) (advanced salary and commissions); Walter Cravens, 3 B.T.A. 282 (1926) (disputed commissions); Eakins v. United States, 36 F.2d 961 (E.D.N.Y. 1930) (salary received by corporation officer under agreement to refund if disallowed as deductions to corporation).

The "claim of right" doctrine does not seem to have made an appearance in state income tax-cases.

19. The company, in 1916, was operating certain oil properties legal title to which 
decree was appealed, and was not affirmed until 1922, the Collector of Internal Revenue considered the earnings properly taxable in 1917. The company, prompted by the hope of a tax saving, contended that the net profits should be allocated either to 1916, the year in which they had been earned, or to 1922 , the year in which the company's right to the monies was finally established. But the Supreme Court, in setting 1917 as the proper tax year, unanimously declared that the earnings became taxable income when the company "first became entitled to them and when it actually received them." The Court concluded that if uncertain income is received under a "claim of right" and without restriction as to its use, tax liability is immediately incurred. ${ }^{20}$

Whether the oil company's "claim of right" derived from its claim to the income or from its legal right thereto is not made clear in the opinion. Analogy to real property doctrine, from which this "claim of right" language was apparently borrowed, supports the interpretations based on the taxpayer's claim rather than on legal right. ${ }^{21}$ But the Supreme Court nowhere

stood in the name of the United States. The Government, claiming the beneficial ownership, instituted suit to oust the taxpayer from possession and in 1916 secured the appointment of a receiver to operate the property and hold the net income thercof. In 1917 a decree was entered dismissing the bill. The Government took an appeal without supcrsedeas, and the money impounded was paid to the defendant corporation. 286 U.S. 417, 421 (1932).

20. Id. at 424. That the oil company was on the accrual basis of accounting was considered immaterial. The Court apparently asserted that acerual may precede receipt of income, but may not follow it. Ibid. This notion has been severely criticized as a departure from "good accounting practice" See Goldstone, Aspccts of Recogrition of Tasable Income Upons the Accrial Basis, XII Tax Miac. 474, 477 (1934): ". . . [A]ßs accrual of money means the establishtsment of an smeonditional right to it, cither before or after its receipt. And the corollary follows that the physical receipt of the money has nothing to do with the reflection of income upon the accrual basis." Lasser and Peloutst, Tas Accounting v. Commercial Accounting, 4 TAX L. Rev. 343, 353-4 (1949) ; Alo:irgosIfRy, Accounting and the Concept of Income in Lectures o: Trxision 55 (1932).

A problem distinct from "claim of right," although analogous thereto, is presented where the right of an accrual basis taxpayer to reccine income, rather than his right to retain it, is still in doube. Courts have generally held such contingent income non-tas:able. E.g., Lucas v. North Texas Lumber Co., 231 U.S. 11 (1930). But of. Commissioner v. Brooklyn Union Gas Co., 62 F.2d 505 (2d Cir. 1933), where earnings impounded during litigation were held to be income of the years earned, not of the year in which the litigation terminated. Judge Learned Hand dissented: "It is sometimes possible, when accounts are kept on an accrual basis, to ignore the conditional character of the right, but that is just what, as I read it, was denied in North Ameriean Oil Consol. v. Burnet [286 U.S. 417 (1932)] in a closely similar situation; the right unaccompanied by possession or its equivalent was too contingent." Id. at 507 .

Whether the deposit of funds in escrow is sufficient to impose restriction on its use and enjoyment so as to preclude taxability until released evidently derends upun the terms and circumstances of the escrow. See Stoner v. Cummissioner, 79 F.2d 75, 76 (3d Cir. 1935) ; 2 Coondinators, op. cit. supra note $11, \$ 212.17 ; 2$ ALErens $\$ 12.105$.

21. The "claim of right" which courts require to establish adverse possession in land is the objective manifestation of an intention to use property as one's ovin regard- 
attempted to spell out the oil company's manifestation of a claim to ownership in $1917 .^{22}$ Moreover, since the company had not received the income until entry of a final decree in its favor, the Court might easily have been referring to a legally recognized claim arising from the judicial determination.

Despite the ambiguities inherent in the debut of "claim of right" in tax law, the bulk of subsequent decisions employing that phrase have sanctioned assessments in a variety of cases merely because the taxpayer received and treated the money as his own: ${ }^{23}$ for example, where funds were received under a contested claim and were subsequently adjudged to be the property of another; ${ }^{24}$ where retention of monies was contingent upon business expectations which might not or did not materialize; ${ }^{25}$ where income had been derived from an unlawful transaction and had to be returned; ${ }^{20}$ or where

less of the interests of others. See Bowden-Gazzam Co. v. Hogan, 22 Wash.2d 27, 34-7, 154 P.2d 285, 289-90 (1944); Rupley v. Fraser, 132 Minn. 311, 313, 156 N.W. 350, 351 (1916) ; 4 Tiffany, Real Property $\$ 1147$ (3d ed., Jones, 1939).

22. The company had not even included the receipts in its tax return for that year.

23. An ample collection of cases may be found in 2 MERTENs $\$ 12.103$; Note, 154 A.L.R. 1276 (1945).

24. McDuffie v. United States, 19 F.Supp. 239 (Ct.Cl. 1937) (proceeds from operation of oil property under leases fraudulently obtained); The Parkland Improvement Co., P-H 1941 BTA MEMr. DEC. SERv. \ 41,580 (1941) (income from illegal operation as a profit corporation); D. H. Byrd, 32 B.T.A. 568 (1935) (one half of taxpayer's profits from sale of land adjudged, under prior contract, to belong to another). Sec Plumb, Income Tax on Gains and Losses in Litigation, 26 CoRN. L. Q. 16-21 (1940).

25. Brown v. Helvering, 291 U.S. 193 (1934) (advanced commissions which insurance agent anticipated from past experience might have to be returned because of cancellations); Jacobs v. Hoey, 136 F.2d 954 (2d Cir. 1943) (commissions as executor received subject to approval of surrogate); First Nat. Bank v. Commissioner, 107 F.2d 141 (6th Cir. 1939) (proceeds of a note subject to be repaid in following year if a certain sale was not consummated); S. B. Heininger, 47 B.T.A. 95 (1942), rev'd on other grounds, 133 F.2d 567 (7th Cir. 1943), af'd, 320 U.S. 467 (1943) (deposits received by dentist selling false teeth by mail, under agreement to refund in case of dissatisfaction). But cf. Wells v. United States, 64 F.Supp. 476 (1946) (advances to employee under profit sharing plan, and refunded when adjustment was made, held not taxable to employee).

26. Dividends: St. Regis Paper Co. v. Higgins, 157 F.2d 884 (2d Cir. 1946) (rcceived contrary to the provisions of its subsidiary's bond indenture); Penn v. Robertson, 115 F.2d 167 (4th Cir. 1940) (received under stock allotment plan and returned when plan was held void); Schramm v. United States, 36 F.Supp. 1021 (Ct. C1. 1941) (liquidating dividend returned to pay deficiency assessment).

Bomus: Griffin v. Smith, 101 F.2d 348 (7th Cir. 1938) (received in years 1930-32 and returned in 19:3 under threat of suit by minority stockholders); National City Bank of New York v. Helvering, 98 F.2d 93 (2d Cir. 1938) (received in 1922 and 1923, returned in 1925 following Senate investigation).

Excessive salaries: Saunders v. Commissioner, 101 F.2d 407 (10th Cir. 1939) (received in years 1929-31 and repaid in 1932 when right thereto was questioned by receiver of corporation in court proceedings); Alfred J. Fleischer, P-H 1945 TC Meas. DEC. SERv. $\llbracket 45,380$ (1945) (returned when disallowed as deduction to corporation). But see note 33 infra.

Cases involving taxation of gains from illegal activities, as distinguished from unlawful transactions, are cited in note 39 infra. 
income was received without passage of "title" and was later restored to its rightful owner. ${ }^{27}$ Thus the "personal claim" doctrine seems well established.

But courts are not always willing to sustain taxation merely because the taxpayer received and treated the monies as his own. The Court of Claims, for example, has held that a taxpayer's original claim to receipts may be neutralized by later events which show that he received the income temporarily by "mistake." 28 In employing this device, the Court is obviously circumventing the annual accounting rule in order to defeat taxation which it considers extremely unjust. ${ }^{29}$ Although most courts have frowned on such a maneuver, ${ }^{30}$ others have concocted further exceptions to "claim of right." Inequitable taxation has sometimes been avoided by judicial assertions that

27. E.g., Penn v. Robertson, 115 F.2d 167 (4th Cir. 1940), where dividends were held taxable to the recipient although the stock allotment plan under which they had been paid was declared void ab initio. Judge Parker, while concurring in the result, asserted: "In my view, the stock transaction was not absolutely roid but roidable. . . If, however, I were of the opinion that the stock transaction was absolutely void, ab initio, and not merely voidable I would think that no taxable income resulted from the entry of the credit for dividends on the note of Penn. If the stock transfer was void, the credit of the dividends was likewise void. No taxable income could possibly result from void entries of credit on a void note. Ex nihilo, nihil fit." Id. at 177. Kurrle v. Commissioner, 126 F.2d 723 (Sth Cir. 1942) (embezzled fund taxable to embezzler). Contra: Commissioner v. Wilcox, 327 U.S. 404 (1946) discussed at pp. 962-3 infra; Ford v. Nauts, 25 F.2d 1015 (N.D.Ohio 192S). See notes $3 S$ and 39 infro.

28. In Gargaro v. United States, 73 F.Supp. 973 (Ct.Cl. 1947), a corporate officer was held entitled to recover tax paid on that portion of his 1942 bonus which was returned in 1944, upon Government renegotiation of his firm's profits from var contracts. Indignant at the Government's effort to retain taxes upon sums which it had itself recouped, the court declared: "For the Government to insist upon keeping taxes paid to it by a taxpayer under the mistaken belief that he had received income for his own use and benefit, when in fact he received it only by reason of an honest mistalte ... there is nothing to be said morally." Id. at 974. See Notes, 61 HARv. L. REv. 710 (1948) and 95 U. PA. I. REv. 574 (1948), approving the decision.

And see Greenwald v. United States, 57 F.Supp. 569 (Ct. C1. 1944). Ordering a refund of taxes on a bonus based upon a fraudulent overstatement of profits and returned when the falsification was discovered, the Court of Claims leveled a blast at "claim of right": "Where ... one pays income taxes upon income which he physically receives, but which he is not allowed to keep, the Government's retention of the tas is essentially unjust ... [W] [Were, due to ignorance of fact, the taxpayer had no choice in the matter, that injustice is complete. Even in the case of questioned income, if the taspayer honestly believes he has a right to the income, it is unjust to require him, in effect, to give up the income in order to keep himself free from liability to the Government." Id. at 573. Cf. Wells v. United States, 64 F.Supp. 476 (Ct.C1. 1946). Contra: MfeDuffie v. United States, 19 F.Supp. 239 (Ct.C1. 1937).

Something in the nature of a "mistake" theory seems to have enjoyed popularity with the Board of Tax Appeals prior to the North American decision. V. T. Lilly, 14 B.T.A. 703 (1928); Walter Cravens, 3 B.T.A. 282 (1926); Carey Van Fleet, 2 B.T.A. 825 (1925).

29. See note 28 supra.

30. See cases cited in Gargaro v. United States, 73 F.Supp. 973, 976 (Ct.C1. 1947) (dissenting opinion). 
the taxpayer received and held income only under compulsion of law, ${ }^{31}$ or as the agent ${ }^{32}$ or debtor ${ }^{33}$ of another. And the conclusion that a taxpayer held monies in "constructive trust" for their rightful owner has similarly provided tax refunds for taxpayers who would have been unable to obtain a compensating deduction in the year of restitution. ${ }^{34}$

Unfairness to a third party may also inspire exceptions to the personal "claim of right" criterion. This factor may account for the Supreme Court's decision in Commissioner v. Wilcox, ${ }^{35}$ involving the tax liability of Wilcox on funds which he had embezzled. There, as in the usual embezzlement case, the funds were gone and the defrauded employer was seeking repayment; to have given the United States a tax lien on the remainder of the embezzler's property would have been tantamount to depriving the victim of even partial recoupment. ${ }^{36}$ Faced with this situation, the Court chose to disregard Wilcox's manifest intent to treat the embezzled sums as his own. ${ }^{37}$

31. Sohio Corp. v. Commissioner, 163 F.2d 590 (D.C.Cir. 1947) (under threat of heavy statutory penalties taxpayer withheld from its vendors part of purchase price as taxes on producer, and at same time filed suit to test constitutionality). But cf. Security Flour Mills Co. v. Commissioner, 321 U.S. 281 (1944) (sellor of flour taxable on amount of federal processing tax, afterward declared unconstitutional, although it filed suit to contest constitutionality). See 2 MERTENs $\$ 17.08$.

32. Commissioner v. Turney, 82 F.2d 661 (5th Cir. 1936). Turney had reccived bonuses from the sale of an oil and gas lease, apparently unaware that he was under a duty to pay one half to the State of Texas. The majority of the court declared that at the time Turney received the bonuses it was "apparent to any informed person that . . . [his] claim was wholly unfounded. ..." Id. at 662 . But see the cases mentioned in the vigorous dissent of Judge Hutcheson, ibid. Cf. Paul A. Draper, 6 T.C. 209, 216 (1946).

33. Eakins v. United States, 36 F.2d 961 (E.D.N.Y. 1930) (salaries received in years 1917-18 and returned in 1924 when disallowed as deduction to corporation) i cf. Hanna v. Commissioner, 156 F.2d 135 (9th Cir. 1946) (funds advanced by clients with understanding that balance after deducting costs of litigation should belong to law firm held not taxable at time of advance). But see note 26 supra.

34. In Knight Newspapers v. Commissioner, 143 F.2d 1007 (6th Cir. 1944), the taxpayer, a personal holding company subject to a large surtax on undistributed income, accrued on its books a $\$ 240,000$ dividend declared by its subsidiary. After the close of the taxable year, the dividend was found to violate rights of preferred stockholders, and was rescinded. Implying a constructive trust, the court stated that ordinarily, "if repayment is subsequently required, allowable deductions in a later year would roughly compensate the taxpayer for the tax paid in an earlier year. Here, however, a surtax of some 65 to $75 \%$ is involved, and this cannot be recovered by a deduction for loss claimed in a subsequent year, since tax saving would then be limited by application only of the normal income tax rate" Id. at 1010. The Treasury is not in accord. G.C.M. 16730, XV-1 Cum. Bulz. 179 (1936). Disapproval is also expressed in St. Regis Paper Co. v. Higgins, 157 F.2d 884, 885 (2d Cir. 1946).

35. 327 U.S. 404 (1946). Law review treatment has been abundant. The most worthwhile Notes are 34 CALIF. L. Rev. 449 (1946); 22 IND. L. J. 99 (1946); 25 TEx. L. REv. 693 (1947).

36. The lien would have taken priority over the employer's demand. INT. REv. ConE \$3670. See Glass City Bank v. United States, 326 U.S. 265, 268 (1945).

37. Justice Murphy concluded: "Sanctioning a tax under the circumstances before 
Asserting that the applicable state law leaving "title" to the monies in the employer insulated the embezzler from tax liability, ${ }^{\circ 3}$ the Court held that an embezzler has no "bona fide claim of right"-apparently meaning "legal title"- to his illicit gain. ${ }^{39}$

us would serve only to give the United States an unjustified preference as to part of the money which rightfully and completely belongs to the taxpayer's employer." Commissioner v. Wilcox, 327 U.S. 404,410 (1946). To which Mr. Justice Burton, in lone dissent, replied: "This . . . is hardly an adequate argument to eliminate the tas: itself. At most it is an argument for Congress to modify the tax lien in favor of the victim." Id. at 414 .

38. Id. at 409. But absence of title to funds has not always barred a tax thereon. See cases cited in notes 27 supra and 39 infra; Corliss r. Bowers, 281 U.S. 376, 378 (1930) ("... [T] Taxation is not so much concerned with refinements of title as it is with actual command over the property taxed ..."). The relationship between passing of "title" and "taxable income" seems unclear. Certainly the vague definitions of income by both Congress and the courts have done little to clarify the issue. See note 15 susfro. And see 1 MERTENS $\$ 5.03$ : "The statement often quoted, that "tasation is an intensely practical matter' unconcerned with theoretical considerations, has considerable influence in determining the scope of the term 'income'" But practicalities seem to have been overlooked in the IVilcox decision. To make embezzlers a privileged class of criminal because of the technical incidence of title seems farcical. See note 39 infra. The criminal's enjoyment of the funds is not determined by the method he employed to trap his vietim. Why then should his method determine taxability? Mioreover, maling "title" a universal prerequisite of taxability would jeopardize such doctrines as "constructive receipt" and the accounting theory that income is accruable when the taxpayer has, not title to income, but the unconditional right thereto. See 2 IIERTENs $\S 10$; note 6 supro.

Furthermore, the Court's reasoning in the Irilcox decision itself seems unsound. The Court declared: "For present purposes . . . it is enough to note that a tasable gain is conditioned upon (1) the presence of a claim of right to the alleged gain and (2) the absence of a definite, unconditional obligation to repay or return that which would otherwise constitute a gain. Without some bona fide legal or equitable claim, even though it be contingent or contested in nature, the taxpayer cannot be said to have received any gain or profit within the reach of $\$ 22$ (a)." Commissioner v. Wilcos, 327 U.S. 404, 403 (1946) (italics added). But in some cases the taispayer has been under an "unconditional obligation to repay" that which is taxable to him. See note 10 susra. Moreover, the Wilcox opinion contains inherent contradictions. The Court observed that although the embezzled funds were not taxable, any profit which the embezzler received from their use might be taxed. Commissioner $r$. Wilcos, supra, at $40 S$. Yet the embezzler is under an "unconditional obligation to repay" not only the embezzled property but the gain as well. Restatenent, Restrtution $\$ \$ 128,157$ (1937).

39. The decision reversed the previous administration interpretation of Section 22(a) of the Internal Revenue Code, G.C.M. 16572, XV-1 Cux. BurL. 82 (1935), which had been approved by the Tax Court in Estate of Thomas Spruance, 43 B.T.A. 221 (1941). The Circuits had clashed on the question. Conpare MreKnight v. Commissioner, 127 F.2d 572 (5th Cir. 1942) (not taxable), with Kurrle v. Helvering, 126 F.2d 723 (Sth Cir. 1942) (taxable).

The Wilcos decision appears incompatible with the attitude generally expressed by the Supreme Court toward illegal gains. Since Section 22(a) levied upon income derived "from any source whatever" the Supreme Court had failed to see "any reacon why the fact that a business is unlawful should exempt it from paying the taxes that if lawful it would have to pay." United States v. Sullivan, 274 U.S. 259, 263 (1927) (bootlegging). 
Just as a personal "claim of right" has not always compelled courts to sustain a tax, neither has absence of a claim always preclucled a levy. Taxation has been upheld despite the taxpayer's protestations that receipts rightfully belong to another if there is a "probability" that the taxpayer will eventually retain the monies. ${ }^{40}$ And one court sustained taxation of funds received pursuant to a judgment which was later reversed, on the ground that the taxpayer enjoyed "legal title," even though he had deliberately attempted not to treat the monies as his own. ${ }^{41}$

\section{"Clatm of Rights" Evaluated}

Most recipients of unsettled income who would escape the rigors of annual accounting have thus found small relief in the courts. In the overwhelming number of cases taxation has been imposed on the verbal basis of a personal "claim of right." 42 And where this test would not support a tax on particu-

Consequently, courts had sustained taxation of a variety of illegal gains. E.g., Johnson v. United States, 318 U.S. 189 (1943) ("protection payments" to racketeers); L. Weiner, 10 B.T.A. 905 (1928) (gambling gains). See Note, 166 A.L.R. 891 (1947).

An interesting consequence of the Wilcox decision is the effort by some taxpaycrs to achieve tax immunity by establishing that they are in fact embezzlers. E.g., Wallace H. Petit, 10 T.C. 1253 (1948) (black marketeer); United States va Currier Lumber Co., 70 F. Supp. 219 (D.Mass. 1947) (taxpayer misappropriated corporate funds).

The Treasury Department's interpretation of the decision is as follows: "[T] he mero act of embezzlement does not of itself result in taxable income. . . . However, where the owner condones the taking of the property and forgives the indebtedness, taxable income may result to the embezzler, depending on the facts in the particular case." G.C.M. 24945, 1946-2 Cum. BuLl. 27,28. Query, however, whether gratuitous cancellation of the obligation by the owner would not be a gift non-taxable as income. Sce Helvering v. American Dental Co., 318 U.S. 322, 331 (1943). If so, funds embezzled from a forgiving owner would be taxed at a rate far lower than that applied to honest income.

40. In Boston Consol. Gas Co. v. Commissioner, 128 F.2d 473 (1st Cir. 1942), for example, the amount of unclaimed deposits on gas meters was held taxable income despite the company's insistence that it stood ready to fulfill its contractual obligation to make refunds to customers. Although the company neither professed ownership of the deposits nor had the legal right to do so, the court declared that "refunds and deposits once unclaimed are more than likely to remain unclaimed forever ... [and] as a practical matter, they become income by the passage of time." Id. at 475. "Claim of right" was nowhere mentioned. Also in point is Chicago, R. I. \& P. Ry. v. Commissioner, 47 F.2d 990 (7th Cir. 1931), where overcharges collected from unknown passengers and retained in a suspense account were held taxable income for the year in which receivecl.

41. Commissioner v. Alamitos Land Co., 112 F.2d 648 (9th Cir. 1940), ccrt. denicd, 311 U.S. 679 (1940). The company had presupposed that under applicable state law the recovery was merely a trust fund held subject to the results of the appeal. It therefore immediately banked the receipts, did not set them up on its books as its own, and returned them in a later year when the judgment was reversed. Declaring that the company had misinterpreted state statutes, the court asserted that it "was the absolute owner of the money paid to it and that it was part of its taxable income. . . . The fact that the respondent indicated in its books not to exercise its power of absolute dominion over the fund could not change its status as income." Id. at 651 .

42. See notes $23-7$ supra. The meager chance of escaping the doctrine is cmphasized 
lar items of income, courts have created "legal title" and "probability" tests which would. In relatively few cases have the courts employed counterrules to aid the taxpayer. But since, in any situation involving unsettled income, a court is armed with a battery of tests which give it free rein to tax or not tax, decisions can seldom be predicted. Doctrinal elasticity has only made it more obvious that cases are decided by balancing the hardship to the taxpayer against the Government's generic need for assured revenue and administrative convenience. ${ }^{43}$

Neither consistent application of the personal "claim of right" rule nor of any one of its exceptions can better reconcile these conflicting interests. Universal application of the former doctrine would permit taxpayers to postpone taxation until they choose to recognize income as their own. Moreover, since the taxpayer is usually unaware of any infirmity of title at the time he receives income, his claim to ownership provides an unfair criterion either for imposing a tax or for granting a corresponding refund after restitution.

Nor would a rule making assessments depend upon the technical incidence of "legal title" better resolve the problems which annual accounting poses for the recipient of uncertain income. Since the "title," albeit shaky, usually passes to the recipient, the possibility of avoiding taxation would be slight. Furthermore, resting federal taxation upon the peculiarities of title law has already created tenuous distinctions among taxpayers: a swindler who sells maps to buried treasure, for example, obtains title to his ill-gotten proceeds and may be taxed thereon; ${ }^{44}$ an embezzler, devoid of title, may not. ${ }^{45}$

Consistent use of any of the several fringe doctrines offers no better solution than do the more common tests of personal claim and "legal title."

by Treusch, The Clainz of Right Doctrine-Suggested Methods of Escape in Mislahe Cases in Proceentngs of New York University Seventr Am:und Irstiture o: FedERAI TAIATION 1427, 1430, 1436 (1949). Many commentators have vigorously criticized the doctrine. See MLagind, Taxable Incone 209-10 (1945) ; Mositcosreny, Fedral IricoxIE TAX HANDBOOK 92 (1935-6) (". . . a principle of tasation of almost unbelievable harshness. . . This is taxation of gross income with a vengeance.") ; 1 PAUL Ars DIEnTENS, LAW of FeDERAI INCOME TAXATION $\$ 11.25 \mathrm{n}$. 6S(Supp. 1939) ("The "claim of right theory .... is one of many legally justifiable theories which leave a fairminded person unsatisfied, if not morally shocked. It attempts the medieval trick of pushing logic to extremes."). Compare the more sympathetic attitude in 2 MIErre:is $\$ 12.103$ : "The principle underlying the 'claim of right' theory . . . f finds support in its facilitation of the administration of the taxing statute, and that is probably sufficient justification for its departure from the emphasis on fixation of liability and the importance of contingency underlying the theory of accrual."

43. Courts have often said as much. See, e.g., Gargaro v. United States, 73 F.Supp. 973, 975 (Ct.C1. 1947) ; National City Bank v. Helvering, 9S F.2d 93, 96 (2nd Cir. 1938).

44. Akers v. Scofield, 167 F.2d 718 (5th Cir. 1948), cert. devied, 335 U.S. 823 (1948), noted in 18 Orza. B. A. J. 1752 (1947) and 1 VANDERErLt L. REv. 299 (1948).

45. Commissioner v. Wilcox, 327 U.S. 404 (1946) (see pp. 962-3 suspra). 
The "probability" test predicates assessments on the likelihood, at the close of the taxable year of receipt, that the taxpayer will retain uncertain income. It fails because standards of probability are inevitably so illusive that caseby-case application would pose seemingly insurmountable administrative and judicial difficulties. And even were it possible to determine accurately whether the recipient would or would not retain unsettled income, use of the "probability" test seems highly artificial in those cases where restitution has, by the date of decision, eliminated the problematical element. ${ }^{40}$

Consistent application of the doctrines of "constructive trust" or "mis" take" to aid the taxpayer who cannot take a compensating deduction is also open to objection. Such tests are unfair to the Government, since a taxpayer who makes restitution then could choose to his advantage between suing for an equalizing refund or, if either tax rates or the taxpayer's income have increased, taking a windfall deduction. ${ }^{47}$

But the basic fault of all of these doctrines is that they are addressed to the wrong problem. They seek to resolve the conflict between Government and taxpayer by determining whether uncertain income is immediately taxable. Under cover of "claim of right," most courts have held that it is. In doing so, they have merely restated, behind a doctrinal smokescreen, the annual accounting principle that contingencies beyond the taxable year cannot affect the status of receipts as "gross income." This has generally been unfair to the taxpayer. On the other hand, making unsettled income tax-free until it settles would be equally unfair to the Government. If courts continue to juggle the interests of Government and taxpayer by toying with concepts of taxable income, they will never arrive at a solution fair to both.

\section{RECOMMENDATIONS}

Realistic solution of this dilemma must treat the real basis of dispute: annual accounting. The taxpayer would usually be content to pay taxes

46. Nevertheless, the "probability" test has been proposed by at least one writer. See Note, 22 IND. L. J. 99 (1946). The same writer concludes that past application of "claim of right" has consistently coincided with the objective probability that the taxpayer would keep the income. Id. at 103.

47. This may be illustrated as follows: In year 1 , the taxpayer executes a $\$ 50,000$ judgment and pays a tax thereon of $\$ 10,000$. In year 2 he earns another $\$ 50,000$, but tax rates have now increased to $\$ 25,000$. In year 2 the judgment which had been appealed is reversed, and the taxpayer is forced to return $\$ 50,000$ to the adverse party. (1) If he deducts his loss from income in year two he has no net income and pays no tax. Result: Total income of years 1 and 2 is $\$ 50,000$. Total tax payments are $\$ 10,000$. (2) If the taxpayer is entitled only to a refund of original taxes on the money judgment, the repayment of $\$ 50,000$ is non-deductible as a loss in year 2. Result: Total income of years 1 and 2 is $\$ 50,000$. Total tax payments are now $\$ 25,000$.

While the Treasury might counter windfall deductions by itself suing to impose constructive trusts and thus force refunds, it is extremely unlikely that it will have either the knowledge or manpower necessary for the task. 
on contingent income if the annual accounting system were not so rigid as to preclude an equalizing refund when the taxed income was restored. The Government, on the other hand, emphatically prefers immediate collection of revenue rather than postponement until uncertainties are resolved.

Compromise is possible. First, the "claim of right" theory, together with its doctrinal exceptions, should be discarded. All receipts which meet the substantive standards of "gross income" should be taxable in the year they are received. Discarding the "claim of right" test will not affect these substantive standards, since "claim of right" has been used not to determine the particular items which constitute "gross income," \$3 but rather to fix the year in which those items are properly taxable. Second, the Internal Revenue Code should be amended so that a taxpayer who restores income to its rightful owner must revise his earlier tax return and obtain a refund of the original tax payments. ${ }^{49}$ Third, the taxpayer, when seeking this refund, should not be barred by the present requirement that amended returns be filed within three years of the original return or vithin two years of the tax payment; ${ }^{50}$ because of the strong possibility that restitution may be required years later, a longer period of limitation, such as vithin ten years of the original return, ${ }^{51}$ seems far more appropriate. Finally, where the taxpayer is unable to restore the monies to their rightful owner, the true owner's claim against the estate of the taxpayer should take precedence over the claims of the Government. ${ }^{52}$ Under this scheme, the Government remains assured of immediate revenues. The taxpayer can suffer no future loss from present tavation. And innocent third parties are protected.

These proposals dispense with the doctrinal confusion created by the courts, and should provide a workable solution to the problem of unsettled

48. These are necessarily elastic. See notes 15 and 38 rspro. But there is substantial agreement that not all receipts measure up to the concept of tasiable income. Typical are such items as loans, return of capital or investment, and alimony. See 1 MEETrE:s $\$ 5$. And many receipts such as gift or compensation for injury, are specifically esempt from income taxation by the Internal Revenue Code. See id. $\$ 6$.

49. See note 47 supra.

Tinkering with annual accounting rules has been relatively common since 1918, when Congress allowed losses, in defined situations, to be taken in the succeeding year. Revenue Act of 1918, $\$ 204(\mathrm{~b}), 40$ STAT. 1061 (1919). Other instances are listed in Helvering $v$. Cannon Valley Mrilling Co., 129 F.2d 642, 646 n. 3, (Sth Cir. 1942). Well lnown deviations today are the carry-over and carry-back provisions of the Code. I::T. REr. CODZ $\S \S 122$ (b) (2), 292(c), 294(e), 124(j), 3771(e).

50. INT. REv. CODE $\$ 322(\mathrm{~b})$.

51. The burden which this recommendation might place on the Bureau of Internal Revenue is largely a matter of conjecture. See note $\mathbf{5 3}$ infra. If administrative convenience eventually dictates a shorter time limitation for thus amending returns, the Government should at least reduce potential hardship to the taxpayer by exempting repaid income above a fixed amount (e.g., $\$ 5,000)$ from the limitation.

52. This would appear to eliminate any practical reason for continuing to hold cmbezzled funds tax-free, as in the IVilcox case. See notes 37-9 sipra. 
income. Any inconvenience they may cause the Bureau of Internal Revenue seems a small price for more equitable tax administration. ${ }^{53}$

53. Expert estimates of the burden such a plan would raise are difficult to obtain. The Office of the Commissioner of Internal Revenue has declined to comment officially on the suggested proposals. Letter from Mr. Irving Perlmeter, Information Officer, to Yale Law Journar, March 15, 1949. Mr. Paul E. Treusch, Chief, Brief Review Section, Appeals Division, Office of Chief Counsel, Bureau of Internal Revenue, has written as follows: "My own personal belief, which is certainly somewhat colored by my ten or eleven years at the Bureau, is that further encroachments on the annual system of rcporting income should be very carefully considered from the standpoint of administration as well as from that of 'doing equity' in particular cases." Letter to YALE LAW Jouranst, December 29, 1948.

But Mr. Randolph Paul, former General Counsel of the Treasury and now in private tax practice, has commented: "Certainly such cases as the O.P.A. cases and the cases involving receipt and subsequent repayment by corporate officers of salaries or bonuses found to be unreasonably high produce hardship for well meaning people. I have sometimes thought that the hardships could be eased legislatively by a broadening of the principles of Section 3801 of the Internal Revenue Code to allow amended return or a claim for refund for the year in which the income was received, without reference to the statute of limitations. However, there is little the courts can do about this." Letter to the Yale Law Journat, December 9, 1948.

The possibility that the outlined recommendations would seriously increase administrative difficulties seems slight. During the fiscal year 1948, the Bureau of Internal Revenue paid a total of more than 32 million claims for refunds of taxes collected in 1948 and prior years. These repayments amounted to over two billion dollars. 1948 REp. COM'R OF INT. REv. 3 (1949). A taxpayer may seek refunds for many reasons-c.g., that he erroneously overstated taxable income for a current or prior tax year, or that the Collector erred in disallowing a deduction or declaring particular items taxable. It appears highly unlikely that one additional reason for claiming refunds-restitution of unsettled income-would swamp the Bureau, even should the statute of limitations be lifted in these cases. 